University of Nebraska - Lincoln

DigitalCommons@University of Nebraska - Lincoln

2006

Evaluating Crops for a Flexible Summer Fallow Cropping System

Douglas G. Felter

University of Nebraska-Lincoln

Drew J. Lyon

University of Nebraska-Lincoln, drew.lyon@wsu.edu

David C. Nielsen

University of Nebraska-Lincoln

Follow this and additional works at: https://digitalcommons.unl.edu/panhandleresext

Part of the Agriculture Commons

Felter, Douglas G.; Lyon, Drew J.; and Nielsen, David C., "Evaluating Crops for a Flexible Summer Fallow Cropping System" (2006). Panhandle Research and Extension Center. 11.

https://digitalcommons.unl.edu/panhandleresext/11

This Article is brought to you for free and open access by the Agricultural Research Division of IANR at DigitalCommons@University of Nebraska - Lincoln. It has been accepted for inclusion in Panhandle Research and Extension Center by an authorized administrator of DigitalCommons@University of Nebraska - Lincoln. 


\title{
Evaluating Crops for a Flexible Summer Fallow Cropping System
}

\author{
Douglas G. Felter,* Drew J. Lyon, and David C. Nielsen
}

\begin{abstract}
Substituting a short-season, spring-planted crop for summer fallow when soil water is sufficient at planting might reduce soil degradation without significantly increasing the risk of crop failure. The objectives of this study were to determine the relationship of crop grain or forage yield to plant available soil water at planting. The study was conducted on silt loam soils in 2004 and 2005 at Sidney, NE, and Akron, CO. A range of soil water levels was established with supplemental irrigation before planting. Four crops [spring triticale $(X$ Triticosecale rimpaui Wittm.) for forage, dry pea (Pisum sativum $L$.) for grain, proso millet (Panicum miliaceum $\mathbf{L}$.) for grain, and foxtail millet (Setaria italica L. Beauv.) for forage] were no-till seeded into corn (Zea mays L.) residue in a split-plot design with four replications per location. Triticale forage yield increased by $229 \mathrm{~kg} \mathrm{ha}^{-1}$ for each centimeter of soil water available at planting in 2004. Foxtail millet forage yield and grain yield of proso millet increased by $399 \mathrm{~kg} \mathrm{ha}^{-1} \mathrm{~cm}^{-1}$ and $148 \mathrm{~kg}$ $\mathrm{ha}^{-1} \mathrm{~cm}^{-1}$, respectively, at Akron in 2004. Spring triticale, foxtail millet, and proso millet did not respond to soil water at planting in 2005, when precipitation was above the long-term average. Dry pea did not demonstrate a consistent positive response to soil water availability at planting. Soil water at planting may be a useful indicator of potential yield for selected short-season spring-planted summer crops, particularly when crop production is limited by growing season precipitation.
\end{abstract}

$\mathrm{W}$ INTER WHEAT-FALlow has been the dominant cropping system in the Central Great Plains for many years. Variable precipitation, temperature fluctuations, hail, and other unpredictable conditions make dryland farming in the region inherently risky (Dhuyvetter et al., 1996). Though average precipitation is low, less than $500 \mathrm{~mm}$ annually, the amount can often be half or double the historic annual amount (Cannell and Dregne, 1983). Summer fallow was adopted as a means to store soil water, increasing the chances for successful establishment and development of winter wheat and stabilizing winter wheat yields (Lyon et al., 1995; Dhuyvetter et al., 1996; Peterson et al., 1996; Farahani et al., 1998).

When summer fallow began, fallow management consisted of intensive tillage operations. Only $19 \%$ of precipitation received during summer fallow was stored in the soil for the following winter wheat crop (Greb, 1979). Chemical fallow and no-till management have had positive effects on precipitation storage, but the

D.G. Felter and D.J. Lyon, Dep. of Agronomy and Horticulture, Univ. of Nebraska, Panhandle Research \& Extension Center, 4502 Ave. I, Scottsbluff, NE 69361; and D.C. Nielsen, USDA-ARS Central Great Plains Research Station, 40335 County Road GG, Akron, CO 80720. Journal Series no. 15084 of the Univ. of Nebraska Agric. Res. Div. Received 16 Dec. 2005. *Corresponding author (FelterDouglasG@ JohnDeere.com).

Published in Agron. J. 98:1510-1517 (2006).

Dryland Cropping Systems

doi:10.2134/agronj2005.0341

(C) American Society of Agronomy

677 S. Segoe Rd., Madison, WI 53711 USA efficiency of fallow has been stagnant at about $40 \%$ since the 1970s (Greb, 1983; Unger, 1984; Tanaka and Aase, 1987; Dao, 1993; Peterson et al., 1996).

McGee et al. (1997) suggested that greater water storage efficiency could be achieved by terminating fallow in the spring and planting a summer crop. The principle behind cropping intensification is replacement of soil evaporation with crop transpiration (Farahani et al., 1998). Intensified systems in the region generally produce two crops in $3 \mathrm{yr}$ or three crops in $4 \mathrm{yr}$ through the addition of summer crops such as corn, sunflower (Helianthus annuus L.), sorghum [Sorghum bicolor (L.) Moench], or proso millet.

Dryland cropping systems intensification has exhibited pronounced increases in biomass and grain production on an annual basis (Peterson et al., 1993, 1996; Norwood, 1994; Jones and Popham, 1997). Peterson and Westfall (2004) found intensification of cropping systems increased net return to producers by 25 to $45 \%$ compared with wheat-fallow.

The amount of soil water at planting has been used as an indicator of potential yield in some flexible systems. Bauer (1972) selected crops based on the amount of soil water at planting and determined that the production factor most related to crop growth and grain yield was the quantity of stored soil water. Nielsen et al. (2002) reported a strong positive linear relationship between winter wheat grain yield and available soil water at planting. However, Campbell et al. (1988) found growing season precipitation explained 5.4 and 1.5 times as much yield variability in spring wheat as available spring soil moisture in fallow-seeded and stubble-seeded wheat, respectively. Burt and Allison (1963) used a dynamic programming approach based on soil water levels at planting time to decide whether to plant wheat or fallow. Long-term expected returns per year using the dynamic approach were approximately $\$ 7.40 \mathrm{ha}^{-1}$ more than continuous winter wheat and approximately $\$ 14.80 \mathrm{ha}^{-1}$ greater than a static system of alternate winter wheat and fallow.

Lyon et al. (1995) studied the response of five springplanted crops [corn, sorghum, pinto bean (Phaseolus vulgaris L.), proso millet, and sunflower] to varying initial soil water levels in the year following winter wheat harvest. Dry matter accumulation 12 wk after planting demonstrated a strong positive response to increasing soil water in all crops. However, as the number of days from planting to harvest increased, the response of grain yield to soil water at planting decreased.

Lyon et al. (2004) studied the economics of replacing summer fallow with spring-planted crops. They found proso millet for grain and a forage mixture of oat (Avena sativa $\mathrm{L}$.) + pea were economically competitive with systems involving summer fallow. These crops also add diversity to rotations and increase marketing opportunities. 
Short-season, spring-planted crops may have potential as a summer fallow replacement in a dynamic cropping system based on soil water availability at planting. The objective of this study was to evaluate the response of four short-duration spring-planted crops, with potential for inclusion in dynamic cropping systems in the Central Great Plains, to soil water levels at planting.

\section{MATERIALS AND METHODS}

Research was conducted in 2004 and 2005 at the High Plains Agricultural Laboratory $\left(41^{\circ} 12^{\prime} \mathrm{N}, 103^{\circ} 0^{\prime} \mathrm{W}, 1315 \mathrm{~m}\right.$ elevation above sea level) located near Sidney, NE, and the USDA-ARS Central Great Plains Research Station $\left(40^{\circ} 09^{\prime} \mathrm{N}, 103^{\circ} 09^{\prime} \mathrm{W}\right.$, $1383 \mathrm{~m}$ elevation above sea level) located near Akron, CO. The soil type at Sidney was a Keith silt loam (fine-silty, mixed, superactive, mesic Aridic Argiustolls) with a $\mathrm{pH}$ of 7.0 and an organic matter content of approximately $20 \mathrm{~g} \mathrm{~kg}^{-1}$ in the surface $15 \mathrm{~cm}$. At Akron, the soil type was a Weld silt loam (fine, smectitic, mesic Aridic Argiustolls) with a $\mathrm{pH}$ of 7.0 and organic matter content of about $15 \mathrm{~g} \mathrm{~kg}^{-1}$ in the surface $15 \mathrm{~cm}$.

A randomized complete block experimental design with four replications per field site was used at both locations. Three differential soil water levels at planting served as the whole plot treatments. Four summer annual crops (spring triticale, dry pea, foxtail millet, and proso millet) were the subplot treatments. Differential soil water levels were established before planting with a lateral move drop-nozzle irrigation system, with the exception of Akron in 2005, when a solid-set sprinkler system was used. Whole plot treatments were applied to an area 18.3 by $9.1 \mathrm{~m}$ at Sidney and 24.4 by $12.2 \mathrm{~m}$ at Akron. One set of treatments (low) received no supplemental water. Supplemental water applied in medium- and high-water treatments varied by year and location, and was applied to achieve a range of soil water levels at planting. Plant available soil water levels at planting for each crop are shown in Table 1.

Crop water use was calculated by the water balance method using soil water measurements. Runoff and deep percolation were assumed to be negligible. Biweekly soil water determinations in the 0 - to $30-\mathrm{cm}$ layer were obtained by gravimetric water sampling at Sidney and by time-domain reflectometry at Akron. Gravimetric soil water content was multiplied by soil bulk density for the 0 - to 30 - $\mathrm{cm}$ layer to determine volumetric water content. Soil water measurements at 45,75 , and $105 \mathrm{~cm}$ were made using a neutron probe (Campbell Pacific 503 DR, Campbell Pacific, Pacheco, CA). Gravimetric soil water samples from the plot area were used to calibrate the neutron probe. Measurement sites were located near the center of each subplot. Amount of plant available water was determined by subtracting field-observed lower limits of plant water extraction at each site from the total water content at each sampling interval. Lower limits for water extraction at Sidney were 0.10, $0.11,0.11$, and $0.11 \mathrm{~cm}^{3} \mathrm{~cm}^{-3}$ for the 0 - to $30-, 30$ - to $60-, 60$ - to $90-$, and $90-$ to $120-\mathrm{cm}$ intervals, respectively. These values represent the lowest observed volumetric water contents observed in 2004 at Sidney in either the triticale or pea treatments. At Akron, the values were 0.10, 0.13, 0.09, and $0.07 \mathrm{~cm}^{3} \mathrm{~cm}^{-3}$, respectively, for the same soil depth intervals. These values were determined in millet plots at Akron over a 10 -yr period. Planting soil water measurements for spring triticale and dry pea at Sidney in 2005 were lost, so planting soil water estimates were calculated. Potential evapotranspiration from the date of planting until the next soil water measurement was estimated by the Penman-Monteith method (Jensen et al., 1990). Potential evapotranspiration was multiplied by a crop coefficient of 0.15 , resulting in a value of $3.73 \mathrm{~cm}$, which was subtracted from incident precipitation $(5.05 \mathrm{~cm})$ for the period. This amount $(1.32 \mathrm{~cm})$ was subtracted from the total water content on the second measurement date to determine soil water levels at planting.

Soil samples were taken in the spring before planting, and were grouped together by water treatment at each site. Sampling intervals were 0 to 15,15 to 30,30 to 60,60 to 90 , and 90 to $120 \mathrm{~cm}$. Nutrient needs were based on regional recommendations. No supplemental fertilizer was applied in either year at Sidney. Pea seed was inoculated before planting. At Akron, $67.2 \mathrm{~kg} \mathrm{~N} \mathrm{ha}^{-1}$ was applied on the surface beside each row and $22.4 \mathrm{~kg} \mathrm{P}_{2} \mathrm{O}_{5} \mathrm{ha}^{-1}$ was applied in the row at planting for triticale, foxtail millet, and proso millet in both years. The pea crop at Akron in both years was similarly fertilized with $\mathrm{P}$, but no $\mathrm{N}$ was applied and peas were inoculated before planting.

All crops were no-till seeded into corn stubble. Row spacing was 25 and $19 \mathrm{~cm}$ at Sidney and Akron, respectively. Subplot size was 4.6 by $9.1 \mathrm{~m}$ at Sidney and 6.1 by $12.2 \mathrm{~m}$ at Akron. Planting dates are shown in Table 2. Spring triticale '2700' was sown at $101 \mathrm{~kg}$ seed ha ${ }^{-1}$. 'Carneval' dry pea was sown at $135 \mathrm{~kg}$ seed ha ${ }^{-1}$. 'White Wonder' foxtail millet and 'Sunrise' proso millet were sown at $17 \mathrm{~kg}$ seed ha ${ }^{-1}$. Proso and foxtail millet crops were lost to hail in late July at Sidney in 2004. Establishment of these crops was unsuccessful at Akron in 2005 due to soil crusting and subsequent dry surface soil conditions. Weeds were controlled by hand-weeding during the cropping season. Glyphosate [N-(phosphonomethyl)glycine] was used for weed control during noncrop periods.

Dates of harvest are shown in Table 2. Harvest area varied as a result of differences in harvest method or machinery used, or in some instances, because poor crop stands required a smaller harvest area to ensure adequate stand in the harvest area and immediate surroundings. At Sidney in $2004,5.8 \mathrm{~m}^{2}$ of spring triticale was harvested using a small plot forage harvester. Dry pea was hand-clipped from $8.1 \mathrm{~m}^{2}$ and threshed in the plot using a stationary thresher. At Akron in 2004, spring triticale and dry pea were hand-harvested from $1.1 \mathrm{~m}^{2}$ and $0.6 \mathrm{~m}^{2}$, respectively. Harvest data from two dry pea plots at Akron in 2004 were not considered due to low plant density and unreasonable yield levels. Foxtail millet was harvested from variable areas ranging from 4.9 to $13.0 \mathrm{~m}^{2}$ using a forage harvester. An area of $16.3 \mathrm{~m}^{2}$ was swathed and later combined using a small plot combine with a pickup attachment in the

Table 1. Plant available water in the upper $120 \mathrm{~cm}$ of the soil profile before planting for four spring-planted crops seeded into three beginning soil water levels.

\begin{tabular}{|c|c|c|c|c|c|c|c|c|c|c|c|c|c|}
\hline \multirow[b]{2}{*}{ Location } & \multirow[b]{2}{*}{ Year } & \multicolumn{3}{|c|}{ Spring triticale } & \multicolumn{3}{|c|}{ Dry pea } & \multicolumn{3}{|c|}{ Foxtail millet } & \multicolumn{3}{|c|}{ Proso millet } \\
\hline & & Low & Medium & High & Low & Medium & High & Low & Medium & High & Low & Medium & High \\
\hline \multirow{2}{*}{ Sidney } & 2004 & 3.5 & 6.6 & 13.4 & 3.5 & 6.6 & 13.4 & $-\dagger$ & _ & _ & - & - & - \\
\hline & 2005 & 13.4 & 15.4 & 17.4 & 13.8 & 15.4 & 17.8 & 21.2 & 22.8 & 24.4 & 21.2 & 22.8 & 24.4 \\
\hline \multirow[t]{2}{*}{ Akron } & 2004 & 6.4 & 12.7 & 16.8 & 8.7 & 12.5 & 16.6 & 9.8 & 13.2 & 16.1 & 9.0 & 14.0 & 19.0 \\
\hline & 2005 & 9.8 & 14.4 & 19.9 & 12.1 & 15.7 & 20.5 & - & - & - & - & - & - \\
\hline
\end{tabular}

$\dagger$ Foxtail and proso millet were lost to hail at Sidney in 2004, and soil crusting prevented emergence at Akron in 2005. 
Table 2. Planting and harvest dates for spring-planted crops.

\begin{tabular}{|c|c|c|c|c|c|}
\hline Location & Year & Spring triticale & Dry pea & Foxtail millet & Proso millet \\
\hline \multirow[t]{2}{*}{ Sidney } & 2004 & 6 Apr./23 June & 6 Apr./15 July & - & - \\
\hline & 2005 & 7 Apr./24 June & 7 Apr./20 July & 8 June/16 Aug. & 8 June/30 Aug. \\
\hline \multirow[t]{2}{*}{ Akron } & 2004 & 7 Apr./23 June & 7 Apr./13 July & 2 June/26, 30 Aug. $\dagger$ & 2 June/30 Aug. \\
\hline & 2005 & 4 Apr./24 June & 4 Apr./14 July & - & - \\
\hline
\end{tabular}

$\dagger$ At Akron in 2004, foxtail millet plots receiving the high level of supplemental water were harvested on 26 August as a result of more rapid crop development. The remaining foxtail millet plots were harvested on 30 August.

proso millet plots. At Sidney in 2005, forage crops were harvested with a forage harvester. Harvest areas were $8.1 \mathrm{~m}^{2}$ and $9.3 \mathrm{~m}^{2}$, respectively, for spring triticale and foxtail millet. An area of $18.1 \mathrm{~m}^{2}$ was harvested from the center of dry pea and proso millet plots using a small plot combine. Spring triticale was hand-harvested from $1.2 \mathrm{~m}^{2}$ at Akron in 2005. Dry pea was harvested with a small plot combine from variable plot areas ranging from 18.1 to $19.5 \mathrm{~m}^{2}$.

The targeted harvest date for forage crops was when approximately $50 \%$ of the plants had spikes fully emerged from the stem, however, spring triticale harvest was delayed until about $75 \%$ of the plants had spikes emerged at Akron in 2005 . Rain delayed foxtail millet harvest until $95 \%$ of plants had spikes emerged at Sidney in 2005. At Sidney in 2004, spike emergence for triticale was about 20,50 , and $90 \%$ for the low-, medium-, and high-water treatments, respectively. Foxtail millet at Akron had about 20,50, and $75 \%$ spike emergence for the low, medium and high treatments, respectively. Harvest samples were weighed in the field at harvest moisture, a subsample was taken and oven-dried at $50^{\circ} \mathrm{C}$ until weight remained constant. Dry weights were taken and moisture content determined. Forage quality (dry matter, crude protein, neutral detergent fiber, acid detergent fiber, and relative feed value) was determined by the University of Nebraska Soil and Plant Analytical Laboratory using near infrared analysis (NIRS-5000, Foss North America, Eden Prairie, MN). Moisture and test weight of grain crops were determined using a Dickey-John Grain Analyzer (GAC-2000, Dickey-John, Auburn, IL). Grain yield was adjusted to $150 \mathrm{~g} \mathrm{~kg}^{-1}$ moisture for dry pea and $120 \mathrm{~g} \mathrm{~kg}^{-1}$ for proso millet. Data were analyzed using the GLM and REG procedures in SAS (SAS Institute, 1985). Quadratic responses of yield to planting water content and seasonal water use were tested but not significant for any crop, so analysis is limited to linear models.

\section{RESULTS AND DISCUSSION}

Growing season precipitation and 30-yr normals are shown in Table 3. Precipitation amounts during the April to August period were 89 and $133 \%$ of normal at Sidney in 2004 and 2005, respectively. At Akron, precipitation was 77 and $98 \%$ of normal for the April to August period in 2004 and 2005, respectively. Despite some month-to-month variation, average daily temperatures for the April to August growing season were near normal at both locations in 2004 and 2005 (Table 4).

Table 3. Monthly and growing season precipitation for Sidney and Akron.

\begin{tabular}{|c|c|c|c|c|c|c|c|}
\hline Location & Year & Apr. & May & June & July & Aug. & Apr.-Aug. \\
\hline & & & & & $-\mathbf{c m}-$ & & \\
\hline \multirow[t]{3}{*}{ Sidney } & 2004 & 5.5 & 2.6 & 6.6 & 6.7 & 4.1 & 25.5 \\
\hline & 2005 & 5.4 & 5.0 & 15.4 & 6.0 & 6.3 & 38.1 \\
\hline & 30-yr normal & 3.8 & 7.3 & 7.0 & 5.7 & 4.8 & 28.6 \\
\hline \multirow[t]{3}{*}{ Akron } & 2004 & 4.4 & 4.4 & 6.6 & 4.3 & 3.6 & 23.3 \\
\hline & 2005 & 4.6 & 5.1 & 7.6 & 4.3 & 8.0 & 29.6 \\
\hline & 30-yr normal & 3.6 & 7.6 & 5.8 & 7.5 & 5.7 & 30.2 \\
\hline
\end{tabular}

The low-water treatment represents the amount of water stored in the soil since the previous corn crop. The medium and high treatments received supplemental irrigations to establish a range of preplanting water levels. Water levels were monitored in the upper $120 \mathrm{~cm}$ of the soil profile (Table 1). In general, little difference in plant available water content existed between water treatments in the upper $60 \mathrm{~cm}$ of the profile (data not shown). Plant available water was present in the $60-$ to $90-\mathrm{cm}$ layer in medium-water treatments, and throughout the $120-\mathrm{cm}$ profile in high treatments. In 2005 at Sidney, however, little difference in profile water content existed at foxtail and proso millet planting due to above normal spring rainfall.

\section{Spring Triticale}

Forage yield of spring triticale increased with increased plant available water at planting in 2004 (Table 5). In 2005, the yield response was not significant at either location. This was presumably due to above average rainfall amounts in 2005. Precipitation in June was 222 and $132 \%$ of normal for Sidney and Akron, respectively. This ample amount of precipitation during the crop's peak water requirement period reduced the dependence on soil water reserves for plant function. When all spring triticale data were pooled together, the linear function of plant available water at planting explained more than $55 \%$ of the variability in dry matter yield (Fig. 1a). In 2004, under water-limited conditions, plant available water at planting explained $76 \%$ of dry matter yield variability (Table 5).

Water use explained approximately $65 \%$ of the variability in spring triticale dry matter yield when all data were considered (Fig. 1b). For 2004, water use explained $66 \%$ of dry matter yield differences (Table 6). Previous research has shown seasonal water use and biomass yield are linearly related for a number of crops under water-limited conditions (Hanks et al., 1969; Stewart et al., 1977; Hanks, 1983; Nielsen, 2004). Water use was similar across water treatments in 2005, and the response was not significant. Water use increased as soil water at planting increased, except at Sidney in 2005 (Table 7). When combined across locations and years, plant avail-

Table 4. Average daily temperature for Sidney and Akron.

\begin{tabular}{|c|c|c|c|c|c|c|c|}
\hline Location & Year & Apr. & May & June & July & Aug. & Apr.-Aug. \\
\hline & & & & & ${ }^{\circ} \mathbf{C}-$ & & \\
\hline \multirow[t]{3}{*}{ Sidney } & 2004 & 8.0 & 13.7 & 16.9 & 21.2 & 19.2 & 15.8 \\
\hline & 2005 & 6.7 & 11.9 & 18.4 & 23.3 & 20.4 & 16.1 \\
\hline & 30-yr normal & 6.7 & 12.2 & 18.1 & 21.7 & 20.7 & 15.9 \\
\hline \multirow[t]{3}{*}{ Akron } & 2004 & 9.3 & 15.3 & 18.2 & 21.9 & 20.1 & 17.0 \\
\hline & 2005 & 8.0 & 13.8 & 19.9 & 24.9 & 21.6 & 17.6 \\
\hline & 30-yr normal & 7.8 & 13.3 & 19.1 & 22.6 & 21.6 & 16.9 \\
\hline
\end{tabular}


Table 5. Regression estimates and $p$ values for plant available soil water at planting-yield functions.

\begin{tabular}{|c|c|c|c|c|c|c|}
\hline \multirow[b]{2}{*}{ Crop } & \multirow[b]{2}{*}{ Location } & \multirow[b]{2}{*}{ Year } & \multicolumn{2}{|c|}{ Slope } & \multirow{2}{*}{$\frac{\text { Intercept }}{\text { Estimate }}$} & \multirow[b]{2}{*}{$r^{2}$} \\
\hline & & & Estimate & $p$ value & & \\
\hline \multirow[t]{7}{*}{ Spring triticale } & Sidney & 2004 & 134.8 & $<\mathbf{0 . 0 1}$ & 1069 & 0.76 \\
\hline & & 2005 & 1.9 & 0.99 & 6282 & 0.00 \\
\hline & Akron & 2004 & 292.6 & $<\mathbf{0 . 0 1}$ & 40 & 0.85 \\
\hline & & 2005 & 37.1 & 0.51 & 5499 & 0.04 \\
\hline & both & 2004 & 228.8 & $<\mathbf{0 . 0 1}$ & 568 & 0.76 \\
\hline & & 2005 & 35.8 & 0.42 & 5639 & 0.03 \\
\hline & & both & 292.5 & $<\mathbf{0 . 0 1}$ & 855 & 0.56 \\
\hline \multirow[t]{7}{*}{ Dry pea } & Sidney & 2004 & 53.2 & $<\mathbf{0 . 0 1}$ & 1009 & 0.52 \\
\hline & & 2005 & -7.6 & 0.86 & 1587 & 0.00 \\
\hline & Akron & 2004 & 84.2 & 0.09 & 1032 & 0.32 \\
\hline & & 2005 & 13.5 & 0.43 & 1086 & 0.06 \\
\hline & both & 2004 & 79.3 & $<\mathbf{0 . 0 1}$ & 936 & 0.49 \\
\hline & & 2005 & 7.6 & 0.69 & 1265 & 0.01 \\
\hline & & both & 17.8 & 0.19 & 1311 & 0.04 \\
\hline \multirow[t]{2}{*}{ Foxtail millet } & Sidney & 2005 & -117.6 & 0.38 & 10198 & 0.08 \\
\hline & Akron & 2004 & 398.4 & $<\mathbf{0 . 0 1}$ & 1477 & 0.62 \\
\hline \multirow[t]{2}{*}{ Proso millet } & Sidney & 2005 & 65.5 & 0.13 & 2970 & 0.22 \\
\hline & Akron & 2004 & 83.1 & $<\mathbf{0 . 0 1}$ & 33 & 0.58 \\
\hline
\end{tabular}

able water at planting explained $67 \%$ of the variability in water use (Table 7). In 2004, water availability at planting explained $70 \%$ of water use variability.

Forage quality of spring triticale was impacted by soil water availability at planting in 2004 at Sidney (data not shown). At Sidney in 2004, crude protein decreased from 216 to $183 \mathrm{~g} \mathrm{~kg}^{-1}$ and neutral detergent fiber increased from 584 to $615 \mathrm{~g} \mathrm{~kg}^{-1}$ as soil water at planting increased. Acid detergent fiber (mean $=352 \mathrm{~g} \mathrm{~kg}^{-1}$ ) and relative feed value (Kuehn et al., 1999) $($ mean $=95.8)$ demonstrated no significant differences. Plants in the low- and medium-water treatments demonstrated visual signs of water stress, and plant growth and development were hindered. Harvest occurred when 20, 50, and $90 \%$ of plants were headed in the low-, medium-, and high-
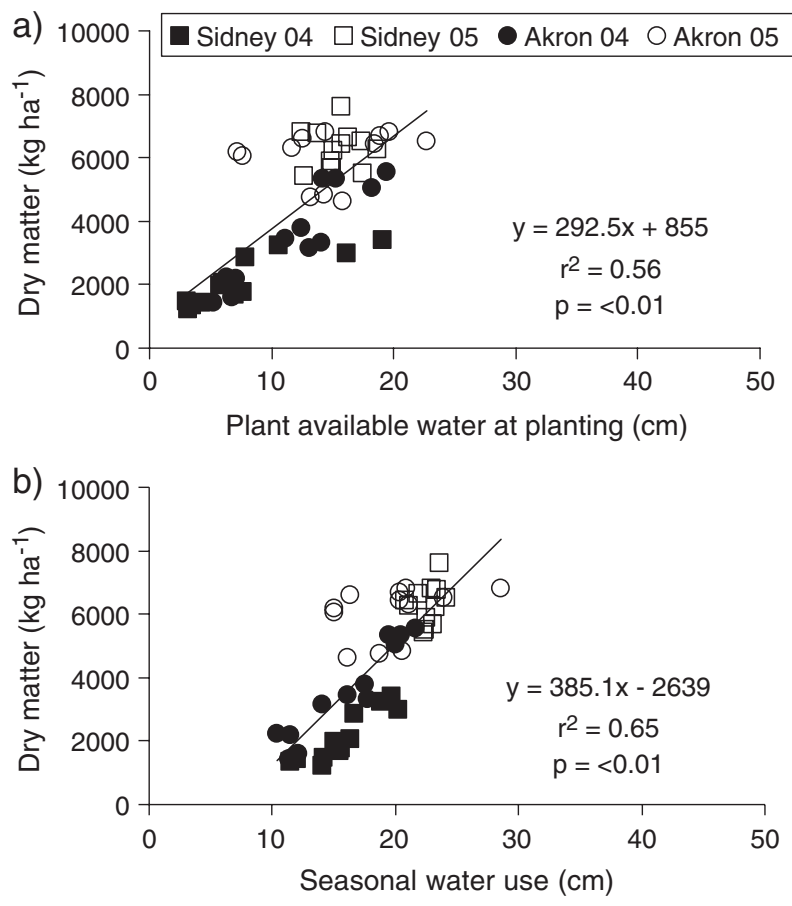

Fig. 1. (a) Plant available water at planting, and (b) seasonal water use-yield relationships for spring triticale.
Table 6. Regression estimates and $p$ values for seasonal water use-yield functions.

\begin{tabular}{|c|c|c|c|c|c|c|}
\hline \multirow[b]{2}{*}{ Crop } & \multirow[b]{2}{*}{ Location } & \multirow[b]{2}{*}{ Year } & \multicolumn{2}{|c|}{ Slope } & \multirow{2}{*}{$\frac{\text { Intercept }}{\text { Estimate }}$} & \multirow[b]{2}{*}{$r^{2}$} \\
\hline & & & Estimate & $p$ value & & \\
\hline \multirow[t]{7}{*}{ Spring triticale } & Sidney & 2004 & 256.0 & $<\mathbf{0 . 0 1}$ & -1918 & 0.82 \\
\hline & & 2005 & 164.6 & 0.41 & 2591 & 0.07 \\
\hline & Akron & 2004 & 354.3 & $<\mathbf{0 . 0 1}$ & -2145 & 0.91 \\
\hline & & 2005 & 79.3 & $\mathbf{0 . 2 3}$ & 4477 & 0.14 \\
\hline & both & 2004 & 329.6 & $<\mathbf{0 . 0 1}$ & -2414 & 0.66 \\
\hline & & 2005 & 86.3 & 0.07 & 4350 & 0.14 \\
\hline & & both & 385.1 & $<\mathbf{0 . 0 1}$ & 2639 & 0.65 \\
\hline \multirow{7}{*}{ Dry pea } & Sidney & 2004 & 61.8 & $\mathbf{0 . 0 3}$ & 204 & 0.38 \\
\hline & & 2005 & 147.1 & 0.04 & -963 & 0.35 \\
\hline & Akron & 2004 & 104.0 & 0.23 & 76 & 0.18 \\
\hline & & 2005 & 11.7 & 0.72 & 1107 & 0.01 \\
\hline & both & 2004 & 59.6 & 0.14 & 556 & 0.11 \\
\hline & & 2005 & 42.4 & 0.21 & 681 & 0.07 \\
\hline & & both & 70.7 & $<\mathbf{0 . 0 1}$ & 272 & 0.19 \\
\hline \multirow[t]{2}{*}{ Foxtail millet } & Sidney & 2005 & -91.6 & 0.29 & 10772 & 0.11 \\
\hline & Akron & 2004 & 728.3 & $<\mathbf{0 . 0 1}$ & 13067 & 0.67 \\
\hline \multirow[t]{2}{*}{ Proso millet } & Sidney & 2005 & 18.3 & 0.51 & 3748 & 0.04 \\
\hline & Akron & 2004 & 147.9 & $<\mathbf{0 . 0 1}$ & 2408 & 0.73 \\
\hline
\end{tabular}

water treatments, respectively. It is likely that differences in maturity resulted in these forage quality differences. Other research has shown similar responses of cereal grain forage quality to maturity at harvest (Twidwell et al., 1987; Ben-Ghedalia et al., 1995; Khorasani et al., 1997). The severity of water stress was impacted by the water treatments and caused differences in maturity. There were no significant differences in forage quality at any other location or year.

Plant available water at planting explained a large proportion of the variability in seasonal water use and dry matter yield, particularly under water-limited conditions, i.e., in 2004. Spring triticale, for forage, may therefore be a good candidate for inclusion in a flexible summer fallow cropping system based on available soil water at planting. With further research, a yield estimation algorithm could be developed for spring triticale that could be used to determine the minimum soil water content at planting necessary to achieve a reasonable yield when water is limiting. Although such an algorithm would likely underestimate yield in years when abundant seasonal precipitation occurs, it would still be a useful tool to mitigate downside yield risk.

Table 7. Regression estimates and $p$ values for plant available water at planting-seasonal water use functions.

\begin{tabular}{|c|c|c|c|c|c|c|}
\hline \multirow[b]{2}{*}{ Crop } & \multirow[b]{2}{*}{ Location } & \multirow[b]{2}{*}{ Year } & \multicolumn{2}{|c|}{ Slope } & \multirow{2}{*}{$\frac{\text { Intercept }}{\text { Estimate }}$} & \multirow[b]{2}{*}{$r^{2}$} \\
\hline & & & Estimate & $p$ value & & \\
\hline \multirow[t]{7}{*}{ Spring triticale } & Sidney & 2004 & 0.5 & $<\mathbf{0 . 0 1}$ & 12.0 & 0.79 \\
\hline & & 2005 & -0.1 & 0.45 & 24.5 & 0.06 \\
\hline & Akron & 2004 & 0.8 & $<\mathbf{0 . 0 1}$ & 6.4 & 0.89 \\
\hline & & 2005 & 0.6 & $<\mathbf{0 . 0 1}$ & 10.9 & 0.55 \\
\hline & both & 2004 & 0.5 & $<\mathbf{0 . 0 1}$ & 10.6 & 0.70 \\
\hline & & 2005 & 0.6 & $<\mathbf{0 . 0 1}$ & 12.9 & 0.38 \\
\hline & & both & 0.7 & $<\mathbf{0 . 0 1}$ & 10.2 & 0.67 \\
\hline \multirow[t]{7}{*}{ Dry pea } & Sidney & 2004 & 1.2 & $<\mathbf{0 . 0 1}$ & -16.3 & 0.80 \\
\hline & & 2005 & 0.3 & 0.61 & 11.4 & $\mathbf{0 . 0 3}$ \\
\hline & Akron & 2004 & 1.5 & $<\mathbf{0 . 0 1}$ & -16.6 & 0.82 \\
\hline & & 2005 & 1.0 & 0.09 & 0.0 & 0.26 \\
\hline & both & 2004 & 1.2 & $<\mathbf{0 . 0 1}$ & -13.4 & 0.56 \\
\hline & & 2005 & 0.8 & $\mathbf{0 . 0 3}$ & 2.8 & 0.19 \\
\hline & & both & 0.3 & 0.28 & 7.8 & 0.03 \\
\hline \multirow[t]{2}{*}{ Foxtail millet } & Sidney & 2005 & 1.0 & 0.02 & 11.8 & 0.45 \\
\hline & Akron & 2004 & 0.5 & $<\mathbf{0 . 0 1}$ & 16.9 & 0.69 \\
\hline \multirow[t]{2}{*}{ Proso millet } & Sidney & 2005 & 1.0 & 0.02 & 15.3 & 0.42 \\
\hline & Akron & 2004 & 0.6 & $<\mathbf{0 . 0 1}$ & 16.2 & 0.78 \\
\hline
\end{tabular}




\section{Dry Pea}

Grain yield of dry pea increased as water at planting increased at Sidney in 2004 (Table 5). Pea yield at Akron was not responsive in either year, and pea yield at Sidney in 2005 also exhibited no response. Pooling the pea data together, the linear function of plant available water at planting explained less than $4 \%$ of the variability in grain yield (Fig. 2a). This response was not significant. In 2004, the quantity of available water at planting explained $49 \%$ of grain yield variability (Table 5).

Water use was impacted by plant available water at planting at both locations in 2004 (Table 7). When only data from 2004 are considered, the linear response of plant available water explained $56 \%$ of the variability in seasonal water use of dry pea. Plant available water explained only $3 \%$ of the differences in water use for dry pea across locations and years.

Pooled across locations and years, the response of pea grain yield to seasonal water use was significant, although the linear function of seasonal water use explained only about $19 \%$ of grain yield variability. Grain yield of dry pea increased by approximately $71 \mathrm{~kg} \mathrm{ha}^{-1}$ $\mathrm{cm}^{-1}$ of water use (Fig. 2b). Other studies have found the response of pea grain yield to be similar at $80 \mathrm{~kg} \mathrm{ha}^{-1}$ $\mathrm{cm}^{-1}$ (Nielsen, 2001), $109 \mathrm{~kg} \mathrm{ha}^{-1} \mathrm{~cm}^{-1}$ (Bortslap and Entz, 1994), and $68.5 \mathrm{~kg} \mathrm{ha}^{-1} \mathrm{~cm}^{-1}$ (Miller et al., 2002).

Dry pea grain yields responded differently in the $2 \mathrm{yr}$ of this study. Previous research has indicated that pea yield is more responsive to the amount of growing season precipitation than stored soil water, particularly during the flowering period (Martin et al., 1994; Baigorri et al., 1999). Pea yields in 2005 were similar to yields in 2004 at both locations despite above normal growing season precipitation in 2005. The low yield was pre-
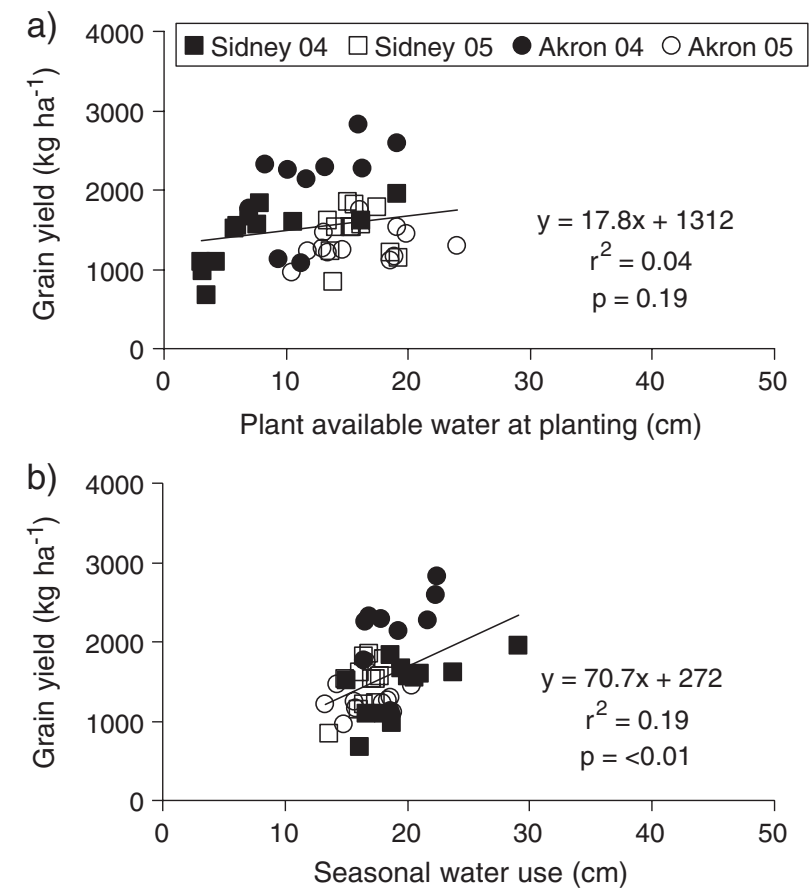

Fig. 2. (a) Plant available water at planting, and (b) seasonal water use-yield relationships for dry pea. sumably due to high temperatures near flowering in 2005. Studies have shown pea yields are adversely affected by temperatures in excess of $25.6^{\circ} \mathrm{C}$ during reproduction (Pumphrey et al., 1979). In 2005, daily highs exceeded $25.6^{\circ} \mathrm{C}$ every day during the approximately 14-d flowering period at both locations. Conversely, in 2004 , only 5 d experienced daily highs greater than $25.6^{\circ} \mathrm{C}$ during flowering at each location.

The quantity of soil water available at planting explained $49 \%$ of dry pea grain yield variability in 2004 , but only $1 \%$ in 2005 . Further understanding of yield stability and conditions that influence pea yield will be necessary for inclusion of dry pea into a flexible summer fallow cropping system based on soil water at planting.

\section{Foxtail Millet}

Data for foxtail millet is limited to two site-years due to hail at Sidney in 2004 and poor emergence at Akron in 2005. Profile water content was similar in all water treatments at Sidney in 2005 and adequate precipitation was received during the growing season. Conditions at Akron in 2004 were water-limited.

At Akron in 2004, foxtail millet dry matter yield increased with soil water at planting (Fig. 3a). The linear function of plant available soil water at planting explained $62 \%$ of the variability in dry matter yield (Fig. 3a). At Sidney, there was not a significant response of yield to soil water at planting. Plant available soil water levels at planting varied greatly between the $2 \mathrm{yr}$ (Table 1), but little difference existed between water treatments at Sidney in 2005.

Water use also responded differently in the $2 \mathrm{yr}$ of the study. Dry matter yield increased as seasonal water use increased at Akron (Fig. 3b). The linear relationship of
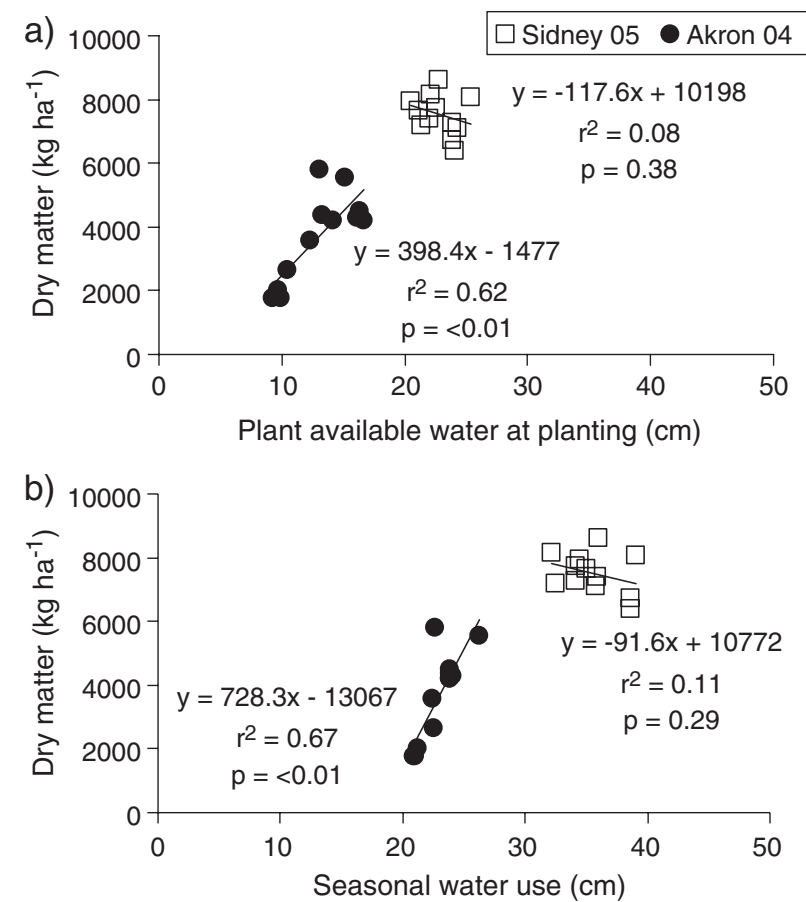

Fig. 3. (a) Plant available water at planting, and (b) seasonal water use-yield relationships for foxtail millet. 
water use explained $67 \%$ of the variability in dry matter. Water use had no significant relationship with dry matter yield at Sidney (Fig. 3b). Water use and yield values were similar for all treatments in 2005.

Plant available water at planting explained $69 \%$ of water use variability at Akron in 2004 (Table 7). Plant available water explained approximately $45 \%$ of the variability in water use at Sidney in 2005 , but the response was different from that at Akron in 2004.

Forage quality of foxtail millet was impacted by water treatments at Akron (data not shown). Crude protein decreased from 190 to $161 \mathrm{~g} \mathrm{~kg}^{-1}$ and acid detergent fiber increased from 298 to $331 \mathrm{~g} \mathrm{~kg}^{-1}$ as soil water at planting increased. Neutral detergent fiber (mean = $536 \mathrm{~g} \mathrm{~kg}^{-1}$ ) and relative feed value $($ mean $=111.4$ ) showed no significant differences across water treatments in 2004. No significant differences existed at Sidney in 2005. Maturity of foxtail millet ranged from less than $25 \%$ spike emergence for low-water treatments to $75 \%$ emergence in high-water treatments at Akron. Visual signs of water stress, and delayed maturity, were evident in the low and medium treatments. Differences in foxtail millet forage quality in 2004 are attributed to maturity differences (Twidwell et al., 1987; BenGhedalia et al., 1995; Khorasani et al., 1997) resulting from differential water stress between water treatments.

The results for foxtail millet forage yield response under water-limited conditions in 2004 indicate that soil water at planting may be an important variable for use in a flexible summer fallow decision support tool for the Central Great Plains. As with triticale, foxtail millet biomass accumulation at Akron in 2004 was strongly related to seasonal water use under water-limited conditions. Plant available water at planting explained $69 \%$ of water use differences at Akron. Additional research will be necessary to further understand the relationship of foxtail millet forage yield and soil water at planting. Preliminary data from this study indicate that it may be possible to determine the lowest soil water level that will provide a reasonable yield in water-limited conditions. Again, nonwater-limited conditions may result in underestimation of yield, but profitable yield levels will still be achieved.

\section{Proso Millet}

Proso millet, like foxtail millet, was also impacted by hail and emergence problems, resulting in only two siteyears of data. The response varied greatly, so site-years were considered independently.

Grain yield of proso millet increased with plant available water at planting at Akron in 2004 (Fig. 4a). Linear regression analysis revealed that $58 \%$ of the variability in grain yield was explained by the quantity of plant available water at planting (Fig. 4a). For Sidney, the response of grain yield to soil water at planting was not significant. Little difference existed in water availability between treatments in 2005 (Table 1 ).

Proso millet grain yield increased as seasonal water use increased at Akron (Fig. 4b). The linear function of water use explained $73 \%$ of grain yield variability. This
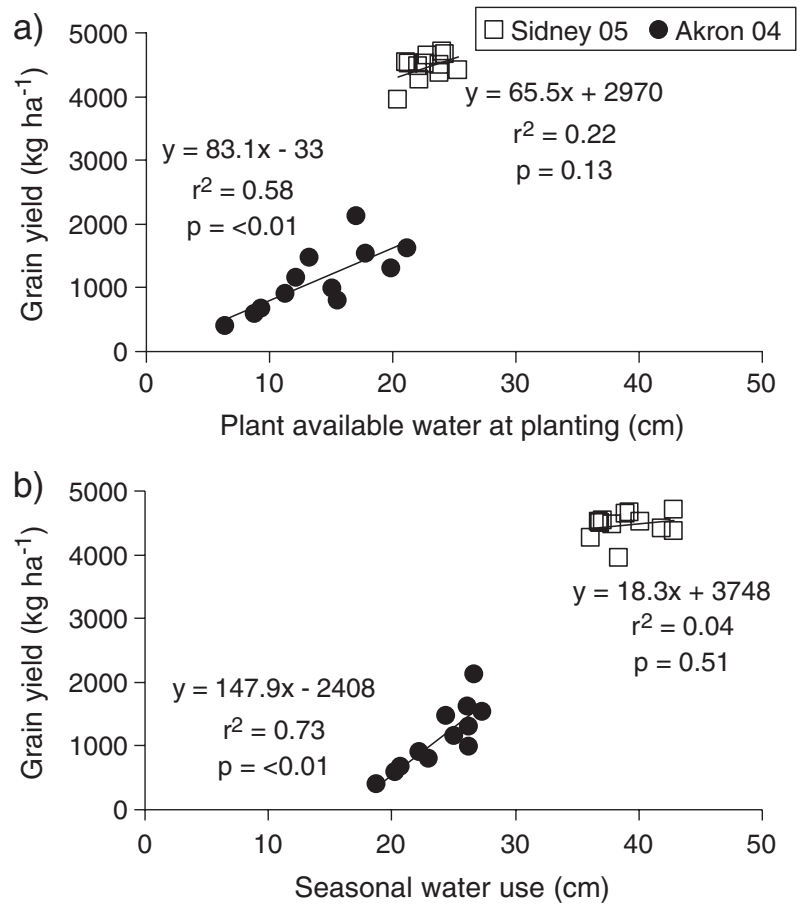

Fig. 4. (a) Plant available water at planting, and (b) seasonal water use-yield relationships for proso millet.

response was not seen for proso millet at Sidney in 2005. The magnitude of yield increase at Akron was approximately $148 \mathrm{~kg} \mathrm{ha}^{-1}$ for each additional centimeter of water use. Shanahan et al. (1988) reported a similar increase of $123 \mathrm{~kg} \mathrm{ha}^{-1}$ for each centimeter of water use, and the linear function of water use explained approximately $85 \%$ of the variability in proso millet grain yield. Plant available water at planting explained $78 \%$ of water use variability at Akron in 2004, but only $42 \%$ for Sidney 2005 (Table 7).

Grain yield of crops is sensitive to timing of water supply. For proso millet, Shanahan et al. (1988) found a linear relationship of grain yield to water use. Proso millet has a low water requirement, possibly the lowest of any cereal (Theisen et al., 1978; Hulse et al., 1980). This is likely attributed, in part, to the $\mathrm{C}_{4}$ photosynthetic mechanism (Martin et al., 1976) and low straw/grain ratio (Greb, 1979).

The efficient water use patterns of proso millet and linear relationship of grain yield to water use indicate that it may be successfully used in a cropping system based on soil water at planting. Additional research will be necessary to further quantify the relationship of proso millet grain yield to plant available water at planting under water-limited conditions. Use of this relationship will help minimize the occurrence of unacceptable proso millet yields for producers.

\section{SUMMARY}

Results of this study indicate the amount of plant available soil water at planting may be a suitable indicator of yield potential for selected short-season, springplanted crops. The forage crops in the study, spring 
triticale and foxtail millet, demonstrated a linear relationship of dry matter accumulation to soil water availability at planting. Proso millet also showed potential as a grain crop for use in a flexible summer fallow cropping system based on soil water at planting. Dry pea did not appear to be suited for such a system. Dry pea yields are unstable and sensitive to temperature and water stress near flowering.

The relationship of soil water at planting to yield is strongest during water-limited years such as 2004 . A decision system based on plant available water at planting may underestimate yield when above normal growing season precipitation is received, but the risk of unacceptable yields will be decreased. Additional research will be necessary to further quantify the relationship of plant available water at planting to yield for the crops demonstrating potential for use in a flexible summer fallow system. It may then be possible to develop a decision support tool to determine when to use a shortseason, spring-planted crop and when to fallow. Market price for the crops will influence the amount of soil water necessary to obtain a minimum acceptable yield, as will other economics such as land and equipment costs.

Selected short-season, spring-planted crops demonstrate potential for use in a dynamic cropping approach to reduce the frequency of summer fallow in the Central Great Plains. Studies are currently underway to determine the impact of these crops and water treatments on yield of the subsequent winter wheat crop.

\section{ACKNOWLEDGMENTS}

The authors would like to express their thanks to Dr. Tim Arkebauer and Dr. David Baltensperger for their advice and counsel during the course of this experiment.

\section{REFERENCES}

Baigorri, H., M.C. Antolin, and M. Sanchez-Diaz. 1999. Reproductive response of two morphologically different pea cultivars to drought. Eur. J. Agron. 10:119-128.

Bauer, A. 1972. Effect of water supply and seasonal distribution on spring wheat yields. North Dakota Agric. Exp. Stn. Bull. 490.

Ben-Ghedalia, D., A. Kabala, J. Miron, and E. Yosef. 1995. Silage fermentation and in vitro degradation of monosaccharide constituents of wheat harvested at two stages of maturity. J. Agric. Food Chem. 43:2428-2431.

Bortslap, S., and M.H. Entz. 1994. Zero-tillage influence on canola, field pea, and wheat in a dry subhumid region: Agronomic and physiological responses. Can. J. Plant Sci. 74:411-420.

Burt, O.R., and J.R. Allison. 1963. Farm management decisions with dynamic programming. J. Farm Econ. 45:121-136.

Campbell, C.A., R.P. Zentner, and P.J. Johnson. 1988. Effect of crop rotation and fertilization on the quantitative relationship between spring wheat yield and moisture use in southwestern Saskatchewan. Can. J. Soil Sci. 68:1-16.

Cannell, C.H., and H.E. Dregne. 1983. Regional setting. p. 6-17. In H.E. Dregne and W.O. Willis (ed.) Dryland agriculture. Agron. Monogr. 23. ASA, CSSA, and SSSA, Madison, WI.

Dao, T.H. 1993. Tillage and winter wheat residue management effects on water infiltration and storage. Soil Sci. Soc. Am. J. 63:186-191.

Dhuyvetter, K.C., C.R. Thompson, C.A. Norwood, and A.D. Halvorson. 1996. Economics of dryland cropping systems in the Great Plains: A review. J. Prod. Agric. 9:216-222.

Farahani, H.J., G.A. Peterson, and D.G. Westfall. 1998. Dryland cropping intensification: A fundamental solution to efficient use of precipitation. Adv. Agron. 64:197-223.
Greb, B.W. 1979. Reducing drought effects on cropland in the westcentral Great Plains. USDA Info. Bull. 420. U.S. Gov. Print. Office, Washington, DC.

Greb, B.W. 1983. Water conservation: Central Great Plains. p. 57-72. In H.E. Dregne and W.O. Willis (ed.) Dryland agriculture. Agron. Monogr. 23. ASA, CSSA, and SSSA, Madison, WI.

Hanks, R.J. 1983. Yield and water-use relationships: An overview. p. 393-411. In H.M. Taylor et al. (ed.) Limitations to efficient water use in crop production. ASA, CSSA, and SSSA, Madison, WI.

Hanks, R.J., H.R. Gardner, and R.L. Florian. 1969. Plant growthevapotranspiration relationships for several crops in the central Great Plains. Agron. J. 61:30-34.

Hulse, J.H., E.M. Laing, and O.E. Pearson. 1980. Sorghum and the millets. Their composition and nutritional value. Academic Press, New York.

Jensen, M.E., R.D. Burman, and R.G. Allen. 1990. Evapotranspiration and irrigation water requirements. ASCE Man. Rep. Eng. Practices No. 70. ASCE, New York.

Jones, O.R., and T.W. Popham. 1997. Cropping and tillage systems for dryland grain production in the southern High Plains. Agron. J. 89:222-232.

Khorasani, G.R., P.E. Jedel, J.H. Helm, and J.J. Kennelly. 1997. Influence of stage of maturity on yield components and chemical composition of cereal grain silages. Can. J. Anim. Sci. 77:259-267.

Kuehn, C.S., H.J. Jung, J.G. Linn, and N.P. Martin. 1999. Characteristics of alfalfa hay quality grades based on the relative feed value index. J. Prod. Agric. 12:681-684.

Lyon, D.J., D.D. Baltensperger, J.M. Blumenthal, P.A. Burgener, and R.M. Harveson. 2004. Eliminating summer fallow reduces winter wheat yields, but not necessarily system profitability. Crop Sci. 44:855-860.

Lyon, D.J., F. Boa, and T.J. Arkebauer. 1995. Water-yield relations of several spring-planted dryland crops following winter wheat. J. Prod. Agric. 8:281-286.

Martin, I., J.L. Tenorio, and L. Ayerbe. 1994. Yield, growth, and water use of conventional and semileafless peas in semiarid environments. Crop Sci. 34:1576-1583.

Martin, J.H., W.H. Leonard, and D.L. Stamp. 1976. Principles of field crop production. Macmillan Publ. Co., New York.

McGee, E.A., G.A. Peterson, and D.G. Westfall. 1997. Water storage efficiency in no-till dryland cropping systems. J. Soil Water Conserv. 52:131-136.

Miller, P.R., B.G. McConkey, G.W. Clayton, S.A. Brandt, J.A. Staricka, A.M. Johnston, G.P. Lafond, B.G. Schatz, D.D. Baltensperger, and K.E. Neill. 2002. Pulse crop adaptation in the northern Great Plains. Agron. J. 94:261-272.

Nielsen, D.C. 2001. Production functions for chickpea, field pea, and lentil in the central Great Plains. Agron. J. 93:563-569.

Nielsen, D.C. 2004. Kenaf forage yield and quality under varying water availability. Agron. J. 96:204-213.

Nielsen, D.C., M.F. Vigil, R.L. Anderson, R.A. Bowman, J.G. Benjamin, and A.D. Halvorson. 2002. Cropping system influence on planting water content and yield of winter wheat. Agron. J. 94: 962-967.

Norwood, C.A. 1994. Profile water distribution and grain yield as affected by cropping system and tillage. Agron. J. 86:558-563.

Peterson, G.A., A.J. Schlagel, D.L. Tanaka, and O.R. Jones. 1996. Precipitation use efficiency as affected by cropping and tillage systems. J. Prod. Agric. 9:180-186.

Peterson, G.A., and D.G. Westfall. 2004. Managing precipitation use in sustainable dryland agroecosystems. Ann. Appl. Biol. 144: 127-138.

Peterson, G.A., D.G. Westfall, and C.V. Cole. 1993. Agroecosystem approach to soil and crop management research. Soil Sci. Soc. Am. J. 57:1354-1360.

Pumphrey, F.V., R.E. Ramig, and R.R. Allmaras. 1979. Field response of peas (Pisum sativum L.) to precipitation and excess heat. J. Am. Soc. Hortic. Sci. 104:548-550.

SAS Institute. 1985. SAS user's guide: Statistics. 5th ed. SAS Inst., Cary, NC.

Shanahan, J.F., R.L. Anderson, and B.W. Greb. 1988. Productivity and water use of proso millet grown under three crop rotations in the central Great Plains. Agron. J. 80:487-492. 
Stewart, J.I., R.E. Danielson, R.J. Hanks, E.B. Jackson, R.M. Hagan, W.O. Pruitt, W.T. Franklin, and J.P. Riley. 1977. Optimizing crop production through control of water and salinity levels in the soil. Publ. PRWG 151-1. Utah Water Lab., Logan.

Tanaka, D.L., and J.K. Aase. 1987. Fallow method influences on soil water and precipitation storage efficiency. Soil Tillage Res. 9:307-316.

Theisen, A.A., E.G. Knox, and F.L. Mann. 1978. Feasibility of in- troducing food crops better adapted to environmental stress. Soil Land Use Technol., Columbia, MD.

Twidwell, E.K., K.D. Johnson, J.H. Cheney, and H.W. Holm. 1987. Forage yield and quality of soft red winter wheats and a winter triticale. Appl. Agric. Res. 2:84-88.

Unger, P.W. 1984. Tillage and residue effects on wheat, sorghum, and sunflower grown in rotation. Soil Sci. Soc. Am. J. 48:885-891. 